\title{
Antiviral Activity of Vitis vinifera Leaf Extract against SARS-CoV-2 and HSV-1
}

\author{
Carla Zannella ${ }^{1}\left({ }^{\circ}\right.$, Rosa Giugliano ${ }^{1}\left(\mathbb{D}\right.$, Annalisa Chianese ${ }^{1}$, Carmine Buonocore ${ }^{2,3} \mathbb{C}^{\circ}$, Giovanni Andrea Vitale ${ }^{3} \mathbb{C}^{\circ}$,

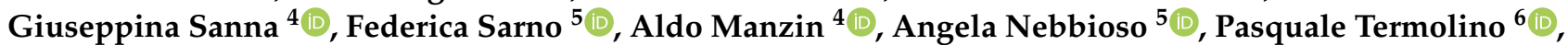 \\ Lucia Altucci $\left.{ }^{5,7}{ }^{(}\right)$, Massimiliano Galdiero ${ }^{1}\left(\mathbb{D}\right.$, Donatella de Pascale ${ }^{3, *}$ and Gianluigi Franci ${ }^{8, *(\mathbb{D})}$
}

1 Department of Experimental Medicine, University of Campania "Luigi Vanvitelli", 80138 Naples, Italy; carla.zannella@unicampania.it (C.Z.); rosa.giugliano@unicampania.it (R.G.); annalisa.chianese@unicampania.it (A.C.); massimiliano.galdiero@unicampania.it (M.G.)

2 Institute of Biochemistry and Cell Biology (IBBC), National Research Council (CNR), 80131 Naples, Italy; carmine.buonocore@szn.it

3 Department of Marine Biotechnology, Stazione Zoologica Anton Dohrn, Villa Comunale, 80125 Naples, Italy; giovanniandrea.vitale@szn.it

4 Department of Biomedical Sciences, University of Cagliari, Cittadella Universitaria, 09042 Cagliari, Italy; g.sanna@unica.it (G.S.); aldomanzin@unica.it (A.M.)

5 Department of Precision Medicine, University of Campania "Luigi Vanvitelli", Vico Luigi De Crecchio 7, 80138 Naples, Italy; federica.sarno@unicampania.it (F.S.); angela.nebbioso@unicampania.it (A.N.); lucia.altucci@unicampania.it (L.A.)

6 Institute of Biosciences and Bioresources (IBBR), National Research Council of Italy (CNR), 80055 Portici, Italy; pasquale.termolino@ibbr.cnr.it

7 BIOGEM, 83031 Ariano Irpino, Italy

8 Department of Medicine, Surgery and Dentistry "Scuola Medica Salernitana", University of Salerno, 84081 Baronissi, Italy

Citation: Zannella, C.; Giugliano, R.; Chianese, A.; Buonocore, C.; Vitale,

G.A.; Sanna, G.; Sarno, F.; Manzin, A.; Nebbioso, A.; Termolino, P.; et al. Antiviral Activity of Vitis vinifera Leaf Extract against SARS-CoV-2 and HSV-1. Viruses 2021, 13, 1263. https://doi.org/10.3390/v13071263

Academic Editor: Albrecht von Brunn

Received: 31 May 2021

Accepted: 25 June 2021

Published: 29 June 2021

Publisher's Note: MDPI stays neutral with regard to jurisdictional claims in published maps and institutional affiliations.

* Correspondence: donatella.depascale@szn.it (D.d.P.); gfranci@unisa.it (G.F.)

Abstract: Vitis vinifera represents an important and renowned source of compounds with significant biological activity. Wines and winery bioproducts, such as grape pomace, skins, and seeds, are rich in bioactive compounds against a wide range of human pathogens, including bacteria, fungi, and viruses. However, little is known about the biological properties of vine leaves. The aim of this study was the evaluation of phenolic composition and antiviral activity of Vitis vinifera leaf extract against two human viruses: the Herpes simplex virus type 1 (HSV-1) and the pandemic and currently widespread severe acute respiratory syndrome coronavirus 2 (SARS-CoV-2). About 40 phenolic compounds were identified in the extract by HPLC-MS/MS analysis: most of them were quercetin derivatives, others included derivatives of luteolin, kaempferol, apigenin, isorhamnetin, myricetin, chrysoeriol, biochanin, isookanin, and scutellarein. Leaf extract was able to inhibit both HSV-1 and SARS-CoV-2 replication in the early stages of infection by directly blocking the proteins enriched on the viral surface, at a very low concentration of $10 \mu \mathrm{g} / \mathrm{mL}$. These results are very promising and highlight how natural extracts could be used in the design of antiviral drugs and the development of future vaccines.

Keywords: SARS-CoV-2; HSV-1; antiviral; antimicrobial; Vitis vinifera; leaf extract; natural extract; flavonoids; molecular networking; LC-MS

\section{Introduction}

Grapevine is one of the major fruit crops worldwide, in terms of economic value and cultivated area. A large amount is subjected to wine production; however, grape has become a model for molecular biology, genetics, and breeding, garnering significant research interest in different areas from the study of polyphenols [1-3] to the investigation of specific gene families, such as resistant genes [4]. 
Grapevine is a plant rich in bioactive compounds [5,6], known for its therapeutic effects. The grape extract was studied for a long time for its hepatoprotective [7], hypoglycemic [8], cardio-protective [9], antioxidant [10,11], antibacterial [11-13], and antiviral activity $[11,14]$ which are due to the high levels of polyphenolic compounds found in grapes skin, seeds, and stem. The anti-cancer effect, that has long been studied over the years, is attributable to the consistent antioxidant activity of these molecules $[15,16]$. Resveratrol, for example, one of the most abundant molecules in the extracts, acts at various levels of carcinogenesis [17]. Grape seed extract inhibits the expression of the epidermal growth factor receptor (EGFR) in head and neck cutaneous squamous cell carcinoma [18], and of MEPK/ERK1-2 and MAPK/p38 in breast cancer, counteracting tumor invasiveness and progression. Some phenolic compounds, such as quercetin and catechins, given their similarity to estrogenic hormones, determine a pro- and anti-estrogenic receptor response in breast cancer [19]. Sharma et al. demonstrated the apoptotic activity of proanthocyanidins blocking COX-2 and the prostaglandin receptor (PGE2) [20]. In this context, two stilbenoids of wine, trans-astringin and trans-piceatannol, also show a cancer-chemiopreventive action by inhibiting cyclooxigenases and precancerous lesions [21]. Recently, Di Meo et al. evaluated the anti-cancer activity of grape seeds semi-polar extracts of two Italian grape varieties (Aglianico and Falanghina). They found that the extracts of both varieties are able to inhibit growth and migration of three different mesothelioma cell lines by activating apoptosis [22].

Antibacterial activity has widely been reported [23-28]. Andelkovic et al. [29] demonstrated that flavonols, phenolic acids, and flavan-3-ols were the main components of grape leaf extracts driving antioxidant and antibacterial activity, principally inhibiting Grampositive bacteria. A similar effect has been observed by Rodriguez-Vaquero et al. [30], who analyzed the antimicrobial potential of three Argentinian wines: Listeria monocytogenes growth was highly reduced by caffeic acid, rutin, and quercetin. Instead, Papadopoulou et al. [31] reported that alcohol-free red and white wine extracts also had antimicrobial potential against Escherichia coli and Candida albicans, albeit it was less strong than that observed against Staphylococcus aureus.

Few studies have analyzed the antiviral activity owned by grapevine extract, mainly related to its potential of inducing disruption of the cell membrane and inhibiting the first phases of the viral life cycle, such as attachment and fusion to the host cell [32-36]. Matias et al. [37] compared the anti-adenoviral activity of Portuguese white-winemaking by-products and resveratrol, used as a standard phenolic compound, and very interestingly, the wine extract was able to inhibit adenovirus- 5 replication after $24 \mathrm{~h}$ post-infection differently from resveratrol. Other studies reported the antiviral potential of grape seed extract (GSE) against Hepatitis C virus (HCV) [38]. Both the crude extract and phenolic compounds caused a significant reduction of HCV replication, as observed by the decrease of gene expression levels in Real-Time PCR. Furthermore, Su et al. [39] described the virucidal activity of GSE against Hepatitis A virus (HAV) and human enteric virus surrogates: the viral replication decreased considerably after treatment at $37^{\circ} \mathrm{C}$ with 0.25 , 0.50 , and $1 \mathrm{mg} / \mathrm{mL}$ GSE. Also, the antiherpetic and anti-parainfluenza activities of Vitis vinifera ( $V$. vinifera) leaves were investigated [38], indicating that fractions of different polarity also had different antiviral potential. The fractioned content derived from chloroform extract showed higher inhibition capability, both against Herpes simplex virus type 1 (HSV-1) and Parainfluenza virus (PIV). Very recently, we characterized the phenolic constituents, antioxidant, antibacterial, and, mainly, the antiherpetic activity of grape cane extracts derived from typical cultivars of Southern Italy [11], i.e., Greco, Aglianico, and Fiano. We prepared various extracts in a range of different $\mathrm{pHs}(1-13)$, demonstrating that the extraction at $\mathrm{pH} 13.00$ was the optimal condition, since the phenolic yield was the highest. We described the presence of 75 compounds with different abundance profiles at various $\mathrm{pHs}$ and, interestingly, six of them were identified for the first time in grape canes. Furthermore, we evidenced that extracts at $\mathrm{pH} 7.00$ and 13.00 were remarkably efficient in the inhibition of the early stages of HSV-1 infection. These data are very promising, 
suggesting that grapevine extracts could be used as cheap and eco-friendly innovative antiviral agents to reduce viral contamination in food and other material intended for human use. In this scenario, we demonstrated that another important source of bioactive compounds, $V$. vinifera leaf extract, had a strong antiviral potential against two important human pathogens, i.e., HSV-1 and the pandemic and currently widespread severe acute respiratory syndrome coronavirus 2 (SARS-CoV-2). The herpetic infection represents one of the most common infectious diseases in humans. The virus can be classified into two types: HSV-1 and type 2 (HSV-2). It has been estimated that 3.7 billion people under the age of 50 (66.6\% of the world's population) are infected by HSV-1 [40]; moreover, the World Health Organization (WHO) has observed that 491.5 million people aged 15-49 years $(13.2 \%)$ have HSV-2 infection. HSV-1 is a common virus infecting humans that is generally transmitted by oral-to-oral contact, but also via the genital route [41,42]. It rarely can also be the causative agent of most severe and fatal diseases, such as keratitis, neonatal infections, and encephalitis. SARS-CoV-2 nowadays represents a serious problem for human health worldwide, both in economic terms and in terms of deaths caused, which to date amount to 3.5 million people [43]. It belongs to the Coronaviridae family, a well-known viral family containing other zoonotic viruses responsible for other pandemic outbreaks caused by SARS-associated coronavirus (SARS-CoV) and Middle East Respiratory Syndrome Coronavirus (MERS). The diseases are very similar and consist of severe acute respiratory infections in humans, characterized by fever, cough, shortness of breath, myalgia, and diarrhea [44]. Despite the advent of vaccines, deaths continue to increase. For these reasons, the identification of new promising drug candidates, especially of natural origin, that are able to interfere with SARS-CoV-2 and HSV-1 is essential.

\section{Materials and Methods}

\subsection{Plant Material}

Green healthy leaves were harvested in April 2019 in Portici (Naples, Italy) from a clone of V. vinifera (var. Paulsen 1103, kindly provided by Dr. Clizia Villano, from University of Naples "Federico II"). The plant has the following descriptive traits: apex is expanded, sublusty, green-bronzed with purplish edges. Apical leaves are showered with light velvet along the ribs of the lower page and are reddish green. The 4th to 6th leaflets are unfolded, whole, orbicular, have a U-shaped petiolar sinus with the base following the main veins, are bristly on the veins of the lower page, and are green with light bronzed reflections; ribs are reddish; petiole has short velvet. The plant stem is curved, ribbed, arachnoid, and purplish-red on one side. Herbaceous shoot is polygonal, with short velvet on the knots and has vinous-red internodes on one side; its knots are brown-purple. Tendrils are violet intermittent, bifid, and triffid; masculine flowers are present. Leaves are medium-sized, kidney-shaped, and whole, they have very open petiolar sinus with the base following the main ribs for a short distance; wavy flap is present; upper page is green, smooth, glabrous, and glossy; underside is light green and has bristly ribs; veins at the base of the upper page are pink; teeth are medium-sized, mucronate, and with convex margins, making it quite regular. Petiole is short, bristly, and vinous red on one side. Woody branch is of medium length and sturdiness, very branched, has a rounded cross section, an almost smooth surface, and a glabrous, grayish color with brown spots; internodes are medium distanced at $12-14 \mathrm{~cm}$; buds are small. The plant blooms and leaves fall in the mid-late period. The plant has bushy habit, excellent vigor, rapid development, and good maturation of the wood; the plant is resistant to phylloxera and some fungal diseases. It is highly compatible with most grafting techniques and adapts to clayey-calcareous, slightly fresh, moderately chlorinated soils, and finally, it tolerates slightly brackish soils. A voucher specimen of this clone is kept and propagated in Portici. Growth conditions are normal open field conditions of the Campania (Italy) region. Fresh leaves were kept on ice and immediately freeze dried and pulverized with pestle and mortar. 


\subsection{Polyphenols Extraction}

Polyphenols were extracted following the procedure developed by Docimo et al., 2016 [45] with some changes. A solution of $1.5 \mathrm{~mL}$ of $75 \%(v / v)$ methanol/0.05\% $(v / v)$ trifluoroacetic acid (TFA) was used for the extraction of $25 \mathrm{mg}$ of pulverized leaf samples, by an incubation at room temperature for $1 \mathrm{~h}$ in continuous orbital shaker at medium speed. After sample centrifugation at $19,000 \times g$ for $10 \mathrm{~min}$, and filtration by $0.2 \mathrm{~mm}$ polytetrafluoroethylene filters, the extract was concentrated in a Vacufuge Concentrator (Eppendorf, Hamburg, Germany) and lyophilized. The powder was solubilized at $100 \mathrm{mg} / \mathrm{mL}$ in DMSO: $\mathrm{H}_{2} \mathrm{O}$ (9:1). The weight ratio of the final lyophilized powder to the dried raw plant material was used to calculate the extraction yield.

\subsection{LC-MS Analysis of Flavonoids}

The extract was dissolved in $\mathrm{MeOH}$ at $5 \mathrm{mg} / \mathrm{mL}$ and an aliquot of $3 \mu \mathrm{L}$ was analyzed through an Information Dependent acquisition (IDA) experiment conducted on a Q-TRAP ${ }^{\mathrm{TM}}$ 4500 (AB Sciex, Framingham, MA, USA) tandem mass spectrometer equipped with an ACQUITY UPLC BEH C18 column (130 ̊, $1.7 \mu \mathrm{m}, 2.1 \mathrm{~mm} \times 50 \mathrm{~mm})$ (Waters, Milford, MA, USA). Full MS spectra were acquired in Enhanced MS (EMS) mode in the $\mathrm{m} / \mathrm{z}$ range $300-1000$, then the 5 most intense ions were subjected to fragmentation in Enhanced Product Ion (EPI) mode. The EPI was conducted in the $m / z$ range 50-1000 with a collision energy (CE) of $-40 \mathrm{eV}$. Both EMS and EPI were conducted in negative mode, with a scan rate of $10,000 \mathrm{Da} / \mathrm{s}$, with the source temperature at $200{ }^{\circ} \mathrm{C}$, capillary voltage of $4.5 \mathrm{kV}$, and de-clustering potential at $-150 \mathrm{~V}$.

The gradient was run at a flow of $200 \mu \mathrm{L} / \mathrm{min}$, using $\mathrm{H}_{2} \mathrm{O}$ and acetonitrile, as solvent $A$ and solvent $B$, respectively, both were supplemented with $0.01 \%$ of formic acid. The adopted gradient was set as follows: from $5 \%$ to $30 \% \mathrm{~B}$ in $20 \mathrm{~min}$, isocratic flow at $30 \% \mathrm{~B}$ for $1 \mathrm{~min}$, from 30 to $100 \%$ B in $5 \mathrm{~min}$, and isocratic flow at 100\% B for $3 \mathrm{~min}$.

\subsection{Molecular Networking and Spectral Library Search}

A molecular network was created with the Feature-Based Molecular Networking (FBMN) workflow [46] on GNPS [47,48]. Firstly, the raw MS data were converted from *.wiff to ${ }^{*}$.mzXML extension through the tool MSconvert tool by ProteoWizard, and secondly processed with MZmine in order to clean the signals, delete the noise, and calculate the peak's area of each compound [43]. The networking description and parameters were automatically generated from GNPS; here, we present a brief extract. The output files were exported to GNPS for FBMN analysis, and the parameters were settled in accordance with the data as follows: the tolerance of the precursor ion mass was set to $2 \mathrm{Da}$ and the tolerance of the $\mathrm{MS}^{2}$ fragment ion was set to $0.5 \mathrm{Da}$. The molecular network was created by setting the edges to have more than 3 matching peaks and a cosine score higher than 0.7 . The maximum size of a molecular family was set to 100 . Analogues were searched for against MS/MS spectra within a range difference of 300 in the precursor ion value. Finally, the molecular network was visualized using Cytoscape. The full description and the GNPS job can be publicly accessed through the link: https:/ / gnps.ucsd.edu/ProteoSAFe/status. jsp?task=5b3274bd0bbd442794c9bbb1721b92f7 (accessed on 28 June 2021).

The relative abundance of the described compound was also calculated. Briefly, the abundance of each polyphenol in Table 1 was calculated as the percentage of its area divided by the sum of all the polyphenols areas. The relative abundance of DGMGs was calculated in the same way but referring to their areas.

$$
\text { Relative abundance }=\frac{\text { Polyphenol area }}{\text { Total polyphenols areas }} \times 100
$$


Table 1. Primers used in Real-Time PCR.

\begin{tabular}{cc}
\hline Gene & sequence \\
\hline HSV-1 UL27 forward & GCCTTCTTCGCCTTTCGC \\
HSV-1 UL27 reverse & CGCTCGTGCCCTTCTTCTT \\
SARS-CoV-2 S forward & AGGTTGATCACAGGCAGACT \\
SARS-CoV-2 S reverse & GCTGACTGAGGGAAGGAC \\
GAPDH forward & CCTTTCATTGAGCTCCAT \\
GAPDH reverse & CGTACATGGGAGCGTC \\
\hline
\end{tabular}

\subsection{Cell Lines and Virus}

Vero cell line (ATCC CCL-81), HCT-116 (ATCC CCL-247), A549 (ATCC CCL-185), MCF7 (ATCC HTB-22), H9c2 (ATCC CRL-1446), HepG2 (ATCC HB-8065), and Hacat (ATCC PCS-200-011) cells were purchased from American Type Culture Collection (ATCC, Manassas, Virginia, United States). Vero cells were grown in Eagle's Minimal Essential Medium (EMEM) supplemented with 10\% Fetal Bovine Serum (FBS), $100 \mathrm{mg} / \mathrm{mL}$ of streptomycin, $2 \mathrm{mM}$ L-glutamine, and $100 \mathrm{IU} / \mathrm{mL}$ of penicillin-streptomycin solution in a humidified atmosphere with $5 \% \mathrm{CO}_{2}$ at $37^{\circ} \mathrm{C}$. HepG2 carcinoma cells were propagated in RPMI-1640 Medium containing $4.5 \mathrm{~g} / \mathrm{L}$ glucose supplemented with 10\% FBS, $100 \mathrm{IU} / \mathrm{mL}$ penicillin-streptomycin, and $2 \mathrm{mM}$ L-glutamine. The other cell lines were propagated in Dulbecco's Modified Eagle's Medium (DMEM) with 10\% FBS, 2 mM L-glutamine and $100 \mathrm{IU} / \mathrm{mL}$ antibiotics. All the materials used for cell culture practice were purchased from Euroclone, Milan, Italy. HSV-1 (strain SC16), carrying a lacZ gene driven by the CMV IE-1 promoter to express $\beta$-galactosidase, was propagated on Vero cells monolayers. SARSCoV-2 (clinical isolate, kindly provided by Lazzaro Spallanzani Hospital, Rome, Italy) was propagated on Vero cells as already reported [49]. All experimental work involving SARS-CoV-2 virus was performed in a biosafety level 3 (BSL3) containment laboratory.

\subsection{Cytotoxicity Test}

Next, $4 \times 10^{4}$ cells/well were plated in a 24-well plate and treated for $48 \mathrm{~h}$, with $V$. vinifera extract at $65,125,250$, and $500 \mu \mathrm{g} / \mathrm{mL}$, and with Vorinostat (SAHA) for $24 \mathrm{~h}$, used as a positive control. The activity of these molecules against the cell viability was determined by the Thiazolyl Blue Tetrazolium Bromide [3-(4,5-dimethylthiazol-2-yl)-2,5diphenyltetrazolium bromide] (Sigma-Aldrich, St. Louis, MO, USA) MTT assay. After treatment with natural extract and SAHA, $0.5 \mathrm{mg} / \mathrm{mL}$ of MTT water solution was added to the cells for $3 \mathrm{~h}$. The purple formazan crystals, after removal of the supernatant, were solubilized in iso-propanol (Carlo Erba Reagents, Cornaredo, Italy) and the absorbance was read at a wavelength of $570 \mathrm{~nm}$ with a TECAN M-200 reader (Tecan, Männedorf, Switzerland).

\subsection{Antiviral Activity}

Vero were plated into 12-well cell culture plates $\left(2 \times 10^{5}\right.$ cells $/ \mathrm{mL}$ for each well $)$ in culture medium. The next day, leaf extract was dissolved in MEM without FBS at the following concentrations: $0.625,1.25,2.5,5,10,50,100$, and $500 \mu \mathrm{g} / \mathrm{mL}$. The antiviral effect was measured following different schemes of treatment, as previously described [50]. The percentage of infectivity inhibition was calculated by counting the number of plaques obtained in the presence of extract with respect to those in CTRL - (only virus without extract). All experiments were performed in triplicate. Greco extract was used as a positive control for HSV-1 and SARS-CoV-2 antiviral assays [11].

\subsection{Gene Expression}

Vero were plated into 12 -well cell culture plates $\left(2 \times 10^{5}\right.$ cells $/ \mathrm{mL}$ cells for each well) in culture medium. The next day, the monolayer was treated with leaf extract and HSV-1 and SARS-CoV-2, as described above. After $24 \mathrm{~h}$, the total RNA was isolated using TRIzol reagent and quantified by measuring the absorbance at 260/280 nm (NanoDrop 
2000, Thermo Fisher Scientific, Waltham, MA, USA). A total of $1 \mu \mathrm{g}$ of total RNA was reverse transcribed to cDNA by $5 \times$ All-In-One RT MasterMix (Applied Biological Materials, Richmond, Canada). A quantitative polymerase chain reaction was run in triplicate using a CFX Thermal Cycler (Bio-Rad, Hercules, CA, USA). Then, $2 \mu \mathrm{L}$ of cDNA were amplified in $20 \mu \mathrm{L}$ reactions using BrightGreen $2 \times$ qPCR MasterMix-No Dye (Applied Biological Materials) and $0.1 \mu \mathrm{M}$ of primer. Relative target $\mathrm{Ct}$ (the threshold cycle) values of UL54, UL52 and UL27 (for HSV-1), and S protein (for SARS-CoV-2) were normalized to GAPDH, as the housekeeping gene. The mRNA levels of cells treated with leaf extract were expressed using the $2^{-\Delta \Delta \mathrm{Ct}}$ method [51]. Primers were purchased by Eurofins (Vimodrone, Milan, Italy) and their sequences are reported in Table 1.

\section{Results and Discussion}

\subsection{Flavonoid Composition of V. vinifera Leaves}

Negative ionization mode HPLC-MS/MS is one of the powerful methods to characterize flavonoids because it provides information on both aglycones and glycosidic conjugates that can differentiate isomers [47,52]. HPLC-MS/MS IDA analysis was carried out to investigate $V$. vinifera leaves metabolic profile.

MZmine [53] and GNPS [54] software were used to convert and analyze the raw MS data, and finally Cytoscape built the complex network shown in Figure 1. Each node indicates a precursor ion, the node size is strongly related to its abundance in the sample (sum precursor intensity), and the edges size between two nodes is directly dependent on their MS/MS spectra similarity (cosine score) [55]. Analysis of GNPS results together with data manual curation evidenced the presence in the network of one big flavonoids cluster together with a smaller one belonging to digalactosylmonoacylglycerol (DGMG) lipids; other unpaired nodes have also been identified during GNPS analysis (Figure 1).

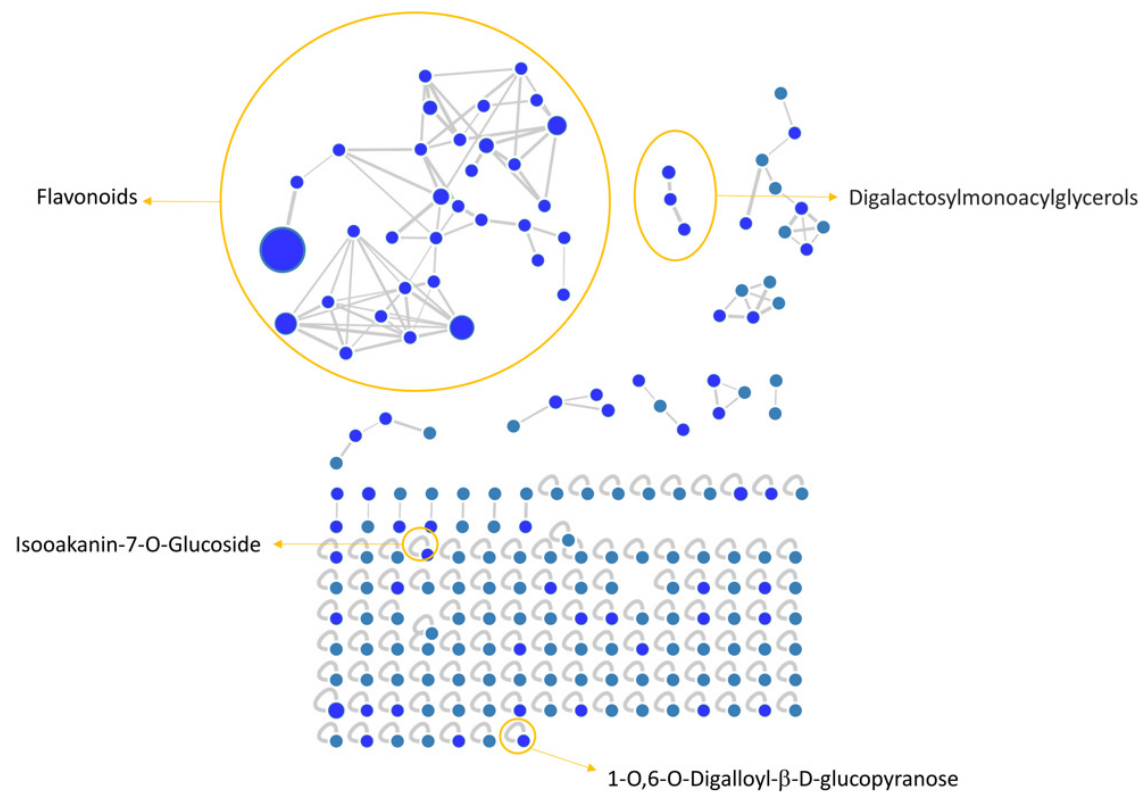

Figure 1. V. vinifera extract Feature Based Molecular Network (FBMN) obtained through GNPS analysis and Citoscape visualization, displaying the presence of flavonoids and digalactosylmonoacylglycerol clusters, together with two unpaired nodes matching with 1-O,6-O-Digalloyl-B-D-glucopyranose and Isookanin-7-O-glucoside.

Assignment of each node has been manually curated and the putative identification is reported in Table 2. Results showed that compound $\mathbf{1}$ was not in a cluster and it was identified by the GNPS annotation tool as the tannin 1-O,6-O-Digalloyl- $\beta$-D-glucopyranose. 
Table 2. Putative assignments of the nodes from the V. vinifera molecular network.

\begin{tabular}{|c|c|c|c|c|c|}
\hline n. & $\begin{array}{l}\text { Precursor Mass } \\
\quad[\mathbf{M}-\mathbf{H}]^{-}\end{array}$ & $\begin{array}{c}\mathrm{Rt} \\
(\mathrm{min})\end{array}$ & Putative Compound & Key Fragments & $\begin{array}{c}\text { Relative } \\
\text { Abundance }\end{array}$ \\
\hline 1 & 482.96 & 5.07 & $\begin{array}{l}\text { Polyphenols } \\
\text { 1-O,6-O-Digalloyl- } \beta \text {-D- } \\
\text { glucopyranose }\end{array}$ & $483 ; 301 ; 312 ; 271 ; 211$ & Traces \\
\hline 2 & 447.22 & 6.34 & Kaempferol-8-C-glucoside & $357 ; 327 ; 297 ; 285$ & Traces \\
\hline 3 & 789.63 & 6.63 & N.I. & $639 ; 613 ; 581 ; 477 ; 465 ; 463$ & Traces \\
\hline 4 & 447.16 & 7.60 & Luteolin-8-C-glucoside (Orientin) & $357 ; 339 ; 327 ; 299 ; 298 ; 297 ; 285$ & Traces \\
\hline 5 & 478.94 & 8.39 & $\begin{array}{l}\text { Myricetin-3-O-beta-D- } \\
\text { galactopyranoside }\end{array}$ & $479 ; 317 ; 316 ; 271 ; 270$ & $0.1 \%$ \\
\hline 6 & 447.03 & 8.47 & $\begin{array}{l}\text { Luteolin-6-C-glucoside } \\
\text { (Isoorientin) }\end{array}$ & $357 ; 339 ; 327 ; 299 ; 298 ; 297 ; 285$ & $16.0 \%$ \\
\hline 7 & 561.36 & 8.73 & N.I. & $449 ; 447 ; 357 ; 327 ; 301 ; 297$ & Traces \\
\hline 8 & 447.05 & 8.88 & $\begin{array}{l}\text { Luteolin-6-C-glucoside } \\
\text { (Isoorientin) }\end{array}$ & $357 ; 327 ; 299 ; 297 ; 285 ;$ & $4.9 \%$ \\
\hline 9 & 447.00 & 9.16 & Luteolin-4-O-glucoside & \multirow{2}{*}{$\begin{array}{c}447 ; 327 ; 285 ; 284 \\
377 ; 353 ; 341 ; 323 ; 311 ; 283 ; \\
282 ; 268\end{array}$} & Traces \\
\hline 10 & 431.03 & 9.45 & Apigenin-8-C-glucoside (Vitexin) & & $0.7 \%$ \\
\hline 11 & 431.06 & 9.85 & $\begin{array}{l}\text { Apigenin-6-C-glucoside } \\
\text { (Isovitexin) }\end{array}$ & $341 ; 323 ; 311 ; 293 ; 283 ; 281 ; 269$ & $13.2 \%$ \\
\hline 12 & 499.07 & 10.02 & N.I. & $499 ; 323 ; 301 ; 300$ & $0.1 \%$ \\
\hline 13 & 477.03 & 10.10 & Quercetin-O-glucuronide & $477 ; 301 ;$ & $44.2 \%$ \\
\hline 14 & 463.07 & 10.30 & $\begin{array}{l}\text { Quercetin-3-O-glucoside } \\
\text { (Isoquercitrin) }\end{array}$ & $463 ; 301 ; 300 ; 271 ; 255$ & $3.3 \%$ \\
\hline 15 & 447.06 & 10.62 & $\begin{array}{l}\text { Biochanin A-7-glucoside } \\
\text { (Astragaloside) }\end{array}$ & $447 ; 327 ; 285 ; 284$ & $4.9 \%$ \\
\hline 16 & 461.06 & 10.81 & $\begin{array}{l}\text { Chrysoeriol 8-C-glucoside } \\
\text { (Scoparin) }\end{array}$ & $371 ; 341 ; 326 ; 313 ; 299 ; 298$ & Traces \\
\hline 17 & 477.09 & 10.83 & Quercetin 3-O-glucuronide & $477 ; 302 ; 301 ; 214$ & Traces \\
\hline 18 & 447.00 & 10.95 & $\begin{array}{l}\text { Luteolin-7-O-glucoside } \\
\text { (Cynaroside) }\end{array}$ & $447 ; 327 ; 285 ; 284$ & Traces \\
\hline 19 & 505.57 & 11.04 & Quercetin-3-O-glucose-6"-acetate & \multirow{2}{*}{$\begin{array}{c}505 ; 301 ; 300 ; 271 ; 255 \\
447 ; 357 ; 327 ; 285 ; 284 ; 255 ; \\
256 ; 227\end{array}$} & Traces \\
\hline 20 & 447.09 & 11.27 & Kaempferol-7-O-glucoside & & $0.3 \%$ \\
\hline 21 & 505.37 & 11.29 & \multirow{2}{*}{$\begin{array}{l}\text { Quercetin-O-Acetyl hexoside } \\
\text { Quercetin-3-O-galactoside } \\
\text { (Hyperoside) }\end{array}$} & $302 ; 301 ; 300 ; 271 ; 255$ & Traces \\
\hline 22 & 462.98 & 11.31 & & $463 ; 301 ; 300 ; 271$ & Traces \\
\hline 23 & 593.15 & 11.54 & $\begin{array}{l}\text { Kaempferol-3-O-(6-O-rhamnosyl- } \\
\text { galactoside) }\end{array}$ & $285 ; 284 ; 257 ; 255$ & Traces \\
\hline 24 & 483.20 & 11.63 & Luteolin-C-hexoside & $483 ; 271$ & Traces \\
\hline 25 & 461.05 & 11.86 & Kaempferol 3-O-glucuronide & $285 ; 257 ; 228$ & $0.6 \%$ \\
\hline 26 & 447.08 & 11.94 & Kaempferol-3-O-glucoside & $447 ; 327 ; 284 ; 285 ; 255 ; 256 ; 227$ & $2.4 \%$ \\
\hline 27 & 517.06 & 12.35 & N.I. & $517 ; 355 ; 341$ & Traces \\
\hline 28 & 491.09 & 12.46 & $\begin{array}{l}\text { Isorhamnetin-3(7)-O- } \\
\text { glucuronopyranoside }\end{array}$ & $491 ; 315 ; 300$ & $8.8 \%$ \\
\hline 29 & 431.01 & 12.95 & Apigenin-7-O-glucoside & $431 ; 283$ & Traces \\
\hline 31 & 463.11 & 13.45 & Quercetin-7-O-glucoside & $300 ; 301$ & Traces \\
\hline 32 & 475.06 & 14.34 & 6-O-Methylscutellarin & $285 ; 284 ; 255 ; 256$ & $0.3 \%$ \\
\hline 33 & 639.15 & 15.22 & $\begin{array}{l}\text { Quercetin-O-glucuronide } \\
\text {-O-hexoside }\end{array}$ & $463 ; 301$ & Traces \\
\hline 34 & 477.06 & 16.24 & $\begin{array}{l}\text { Isorhamnetin-O-glucoside } \\
\text { 4-(3,4-Dihydroxyphenyl)-5-beta- }\end{array}$ & $477 ; 315 ; 314$ & Traces \\
\hline 35 & 461.37 & 18.96 & $\begin{array}{l}\text { D-glucopyranosyloxy-7- } \\
\text { methoxycoumarin }\end{array}$ & $299 ; 284$ & Traces \\
\hline 36 & 449.26 & 19.90 & Isookanin-7-O-glucoside & $449 ; 431 ; 287 ; 269$ & Traces \\
\hline & \multicolumn{5}{|c|}{ Digalactosylmonoacylglycerols } \\
\hline 37 & 675.35 & 24.81 & DGMG 18:3 & $415 ; 397 ; 277 ; 235$ & $97.1 \%$ \\
\hline 38 & 699.34 & 25.54 & DGMG 20:5 & $653 ; 415 ; 397 ; 323 ; 255 ; 235$ & Traces \\
\hline 39 & 653.81 & 25.55 & DMGM 16:2 & $653 ; 415 ; 397 ; 277 ; 255 ; 235$ & $2.9 \%$ \\
\hline
\end{tabular}


A detailed analysis of the MS and MS ${ }^{2}$ spectra, combined with the GNPS annotation tools, lead to the characterization of 35 flavonoids conjugates (see Table 2). Most of them were quercetin derivatives ( 8 compounds), others included derivatives of luteolin (5 compounds), kaempferol (4 compounds), apigenin (3 compounds), isorhamnetin ( 2 compounds), myricetin, chrysoeriol, biochanin, isookanin, and scutellarein (1 compound) (Figure 2). Four flavonoids were not identified (N.I.).

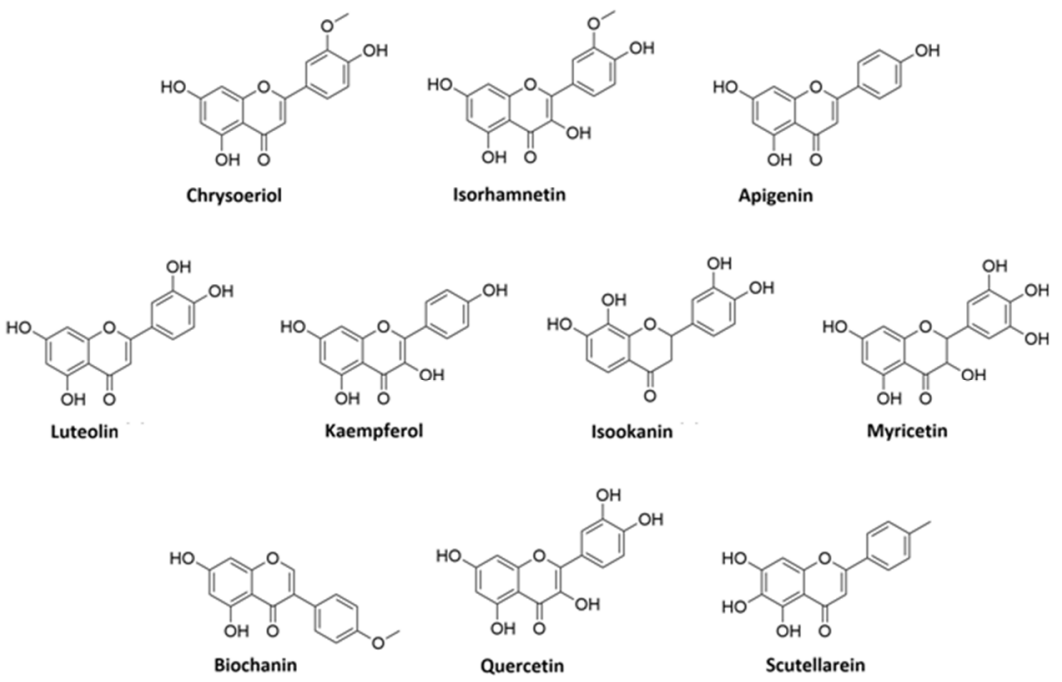

Figure 2. Structures of flavonoid aglycones identified in V. vinifera.

Moreover, we calculated the relative abundance of each compound present in Table 2 within the same chemical class. Results showed that compound $\mathbf{1 3}$ is the most representative among polyphenols, accounting for more than $44 \%$ of the total, followed by compounds 6 and 11, with $16 \%$ and 13\%, respectively. Compounds 8, 14, 15, 26, and 28 account for less than $10 \%$ each, while all the others are present in less than $1 \%$ or traces (Table 2). Among DGMGs, compound 37 is the most representative, with $97 \%$, while compound 38 is present in traces and compound 39 represents $3 \%$ of the cluster.

\subsection{Identification of Kaempferol and Luteolin Derivatives}

The aglycone fragment at $m / z 285$ of compounds 2, 20, 23, 25, and 26 suggested that they originated from kaempferol or luteolin. Compounds 2, 20, and 26 produced a pseudo molecular ion at $m / z 447[\mathrm{M}-\mathrm{H}]^{-}$, and the $\mathrm{MS}^{2}$ profile showed typical fragments of hexose glycoside flavone, as they exhibited peaks at $\mathrm{m} / \mathrm{z} 357[\mathrm{M}-\mathrm{H}-90]^{-}, 327[\mathrm{M}-\mathrm{H}-120]^{-}$, and $297[\mathrm{M}-\mathrm{H}-150]^{-}$. Thus, based on the $\mathrm{MS}^{2}$ fragmentation profile and RT, compound 2 could be assigned as kaempferol-8-C-glucoside, compound $\mathbf{2 0}$ as kaempferol-7-O-glucoside, and compound $\mathbf{2 6}$ as kaempferol-3-O-glucoside [52,56,57].

Compound 23, $\mathrm{m} / \mathrm{z} 593$, is characterized by the neutral loss (NL) of (rhamnosylhexoside) moiety $[\mathrm{M}-\mathrm{H}-308]^{-}$, and by comparison of its $\mathrm{MS}^{2}$ pattern with the literature, we assigned the identity as kaempferol-3-O-(6-O-rhamnosyl-galactoside) [58]. Compound 25 showed the NL of a glucuronide unit $[\mathrm{M}-\mathrm{H}-176]^{-}$and it was assigned as kaempferol3-O-glucuronide.

Compounds 4, 6, 8, 9, and 18 are characterized by the presence of aglycone fragment at $m / z 285$ and they are all isomers with a parental ion at $m / z 447[\mathrm{M}-\mathrm{H}]^{-}$. These isomers were identified through the GNPS database and discriminated by RT as orientin, isoorientin, luteolin-4-O-glucoside, and ymaroside, respectively. Differently, compound 24 showed parental ion at $\mathrm{m} / \mathrm{z} 483$ and was generally assigned as luteolin-C-hexoside, by comparison with a precedent study [59]. 


\subsection{Identification of Apigenin Derivatives}

Compounds 10, 11, and 29 exhibited the same $[\mathrm{M}-\mathrm{H}]^{-}$ion at $m / z$ 431. Compounds 10 and 11 showed a typical fragment of C-glycosides [M - H-120 $]^{-}$at $m / z$ 311. In addition, their $\mathrm{MS}^{2}$ pattern corresponds to the vitexin and isovitexin fragmentation profiles, respectively [58]. The isomer $\mathbf{2 9}$ was generally assigned as apigenin-C-glucoside.

\subsection{Identification of Quercetin Derivatives}

Compounds 13, 14, 17, 19, 21, 22, 31, and 33 are all characterized by the presence of the quercetin aglycone at $\mathrm{m} / \mathrm{z} 301$. Compounds $\mathbf{1 3}$ and $\mathbf{1 7}$ showed parental ion at $\mathrm{m} / \mathrm{z} 477$ $[\mathrm{M}-\mathrm{H}]^{-}$with a NL of $176 \mathrm{Da}[\mathrm{M}-\mathrm{H}-176]^{-}$that is characteristic of the glucuronyl moiety. Compound 17 was identified by the GNPS assignment tool as quercetin-3-O-glucuronide, while its isomer, compound 13, was tentatively identified as quercetin-O-glucuronide [60]. Compounds 14, 22, and 31 showed the same pseudomolecular ion at $m / z 463[\mathrm{M}-\mathrm{H}]^{-}$, showing a NL of a glucoside moiety [M $-\mathrm{H}-162]^{-}$. GNPS assigned compound 14 as isoquercitrin, while compounds 22 and $\mathbf{3 1}$ were tentatively assigned as hyperoside and quercetin-7-O-glucoside, respectively, by the comparison of their RT and $\mathrm{MS}^{2}$ fragments with previous studies $[58,61]$. Compound 19, $m / z 505[\mathrm{M}-\mathrm{H}]^{-}$, was identified by GNPS as Quercetin-3-O-glucose-6"-acetate, while its isomer compound $\mathbf{2 1}$ was generically assigned as quercetin-O-acetyl hexoside [60].

Compound 33, $m / z 639[\mathrm{M}-\mathrm{H}]^{-}$, showed fragments at $m / z 463$ and 301 that correspond to the loss of glucuronyl and hexosyl moieties, respectively. Thus, on this evidence and coherently with a previous study [62], we assigned this compound as quercetin-Oglucuronide-O-hexoside.

\subsection{Identification of Isorhamnetin Derivatives}

Compounds 28 and 34 showed a fragment ion at $\mathrm{m} / \mathrm{z} 315$ that is characteristic of the isorhamnetin aglycone after the NL of a glucuronyl $[\mathrm{M}-\mathrm{H}-176]^{-}$and hexose $[\mathrm{M}$ $-\mathrm{H}-162]^{-}$moiety, respectively. Coherently with the literature, we assigned compound 28 as isorhamnetin3(7)-O-glucuronopyranoside and compound $\mathbf{3 4}$ as isorhamnetin-Oglucoside [63].

\subsection{Other Flavonoids Assignment}

Compounds $5,15,16,32,35$, and 36 were identified by GNPS as myricetin-3-O- $\beta$-Dgalactopyranoside, astragaloside, scoparin, 6-O-methylscutellarin, 4-(3,4-Dihydroxyphenyl)-5beta-D-glucopyranosyloxy-7-methoxycoumarin, and isookanin-7-O-glucoside, respectively.

We could not assign any identification to compounds 3, 7, 12, and 27.

\subsection{DGMG Assignment}

Compound 37 was assigned as digalactosylmonoacylglycerol (DGMG) 18:3 by GNPS annotation tool. By comparison, compounds 38 and 39 were tentatively assigned as DGMG 20:5 and DGMG 16:2, respectively.

\subsection{Antiviral Activity}

In order to evaluate if leaf polyphenol extract had an antiviral potential, and in which stage of the viral infection it could act, we performed experiments in four conditions: (a) simultaneous addition of extract and virus to the cells ("co-treatment"); (b) extract firstly incubated with the virus and then added to the cells ("virus pre-treatment"); (c) extract added to the infected cells ("post-treatment"); and (d) cells treated before with the extract and then infected with the virus ("cell pre-treatment"). The tested range of extract concentrations was from 0.625 to $500 \mu \mathrm{g} / \mathrm{mL}$ both for HSV-1 and SARS-CoV-2, which was used as a virus model for enveloped DNA and RNA viruses, respectively. The percentage of viral inhibition was calculated with respect to the untreated infected control (CTRL-). The reported antiviral activity was very similar for both viruses (Figures 3 and 4), indicating an early effect manifesting directly on the viral envelope. The extract was most effective 
when incubated with HSV-1 and SARS-CoV-2 upon addition to target cells (co-treatment, Figures $3 \mathrm{~A}$ and $4 \mathrm{~A}$ ) or with the virus (virus pre-treatment, Figures $3 \mathrm{~B}$ and $4 \mathrm{~B}$ ) prior to infection on the cell monolayer. No activity was registered when the extract was added after HSV-1 infection (post-treatment, Figures 3C and 4C), while a slight antiviral effect was observed when cells were firstly treated with the extract and then infected (cell pretreatment, Figures 3D and 4D). In detail, leaf extract was able to completely inhibit HSV-1 replication in virus pre-treatment assay until a concentration of $10 \mu \mathrm{g} / \mathrm{mL}$ was obtained but the virus resumed growing at $5 \mu \mathrm{g} / \mathrm{mL}$, though with less efficiency (Figure 3B). Instead, the antiviral activity of $V$. vinifera extract was slightly lower against SARS-CoV-2, as it was set at $80 \%$ at $10 \mu \mathrm{g} / \mathrm{mL}$. As HSV-1, no relevant inhibition was detected when the concentration of the extract was reduced to $5 \mu \mathrm{g} / \mathrm{mL}$.

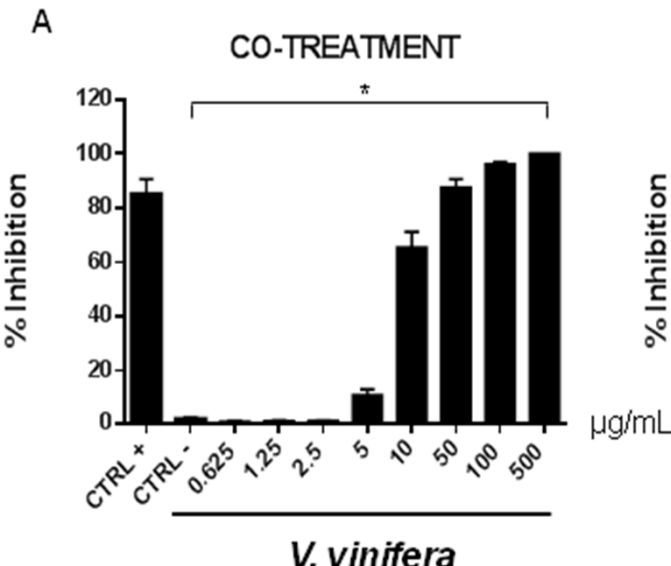

C

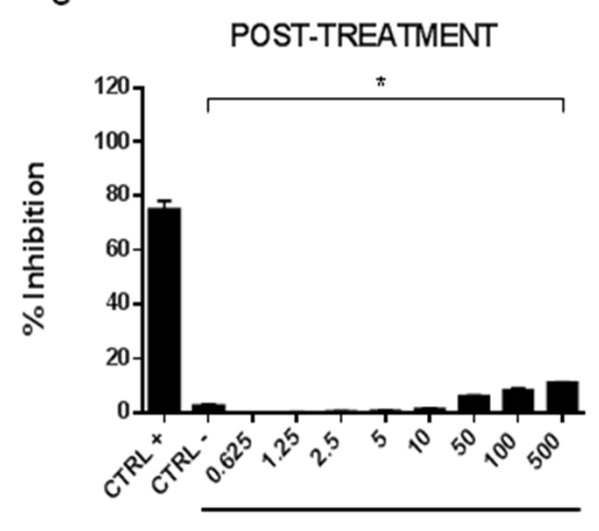

V. vinifera
B

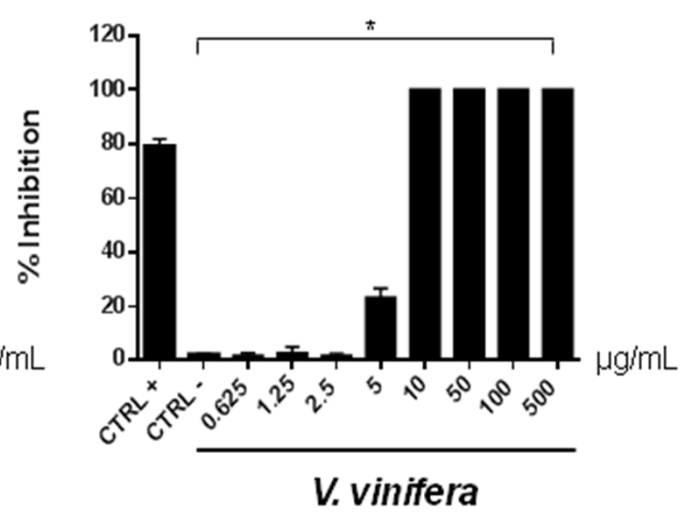

D

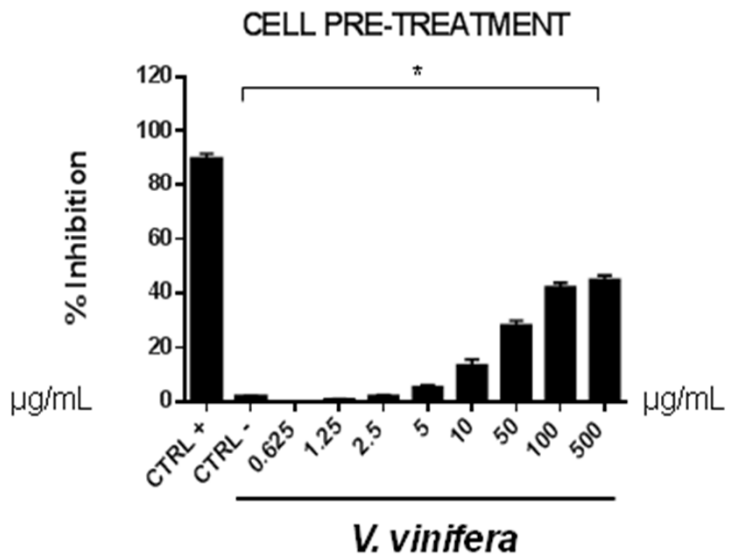

Figure 3. Antiviral effect (expressed as $\%$ of inhibition) of leaf extract $(\mu \mathrm{g} / \mathrm{mL}$ ) against HSV-1 in different plaque reduction assays: (A) co-treatment; (B) virus pre-treatment; (C) post-treatment; (D) cell pre-treatment. The results presented were obtained from three independent experiments. Data are mean \pm SD. Statistical differences were analyzed via Student's $t$-test, a value of $p \leq 0.05$ was considered significant, with * $p \leq 0.05$.

The leaf extract definitely showed a stronger antiviral potential than Greco extract, which was used as a positive control (CTRL+) against HSV-1 and SARS-CoV-2 [11,64-66].

These data are very interesting and indicate that the leaf extract could act directly on viral particles, blocking the interaction with the cell membrane. To deepen the viral inactivation mechanism, another antiviral test was carried out, such as the attachment assay (Figures 5 and 6), by shifting the temperature during the infection at $4{ }^{\circ} \mathrm{C}$. 
A

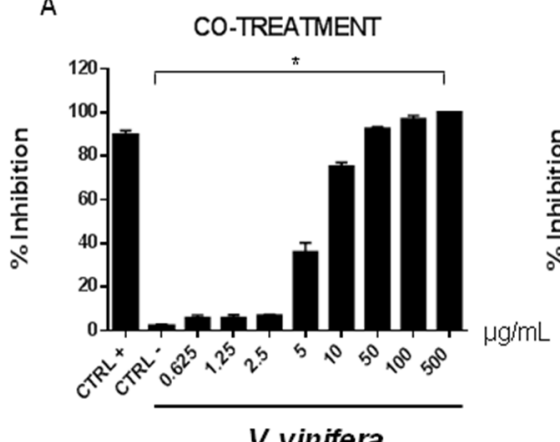

C

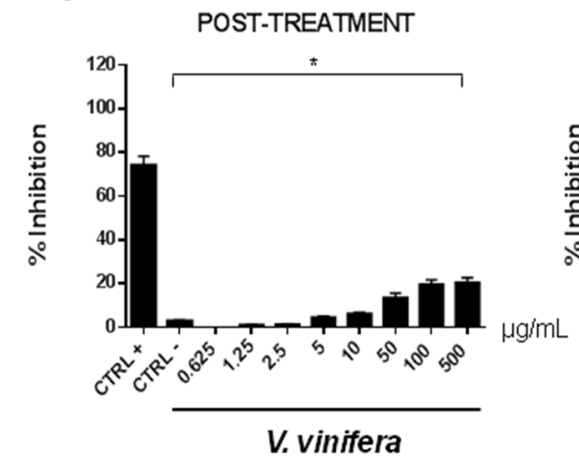

B

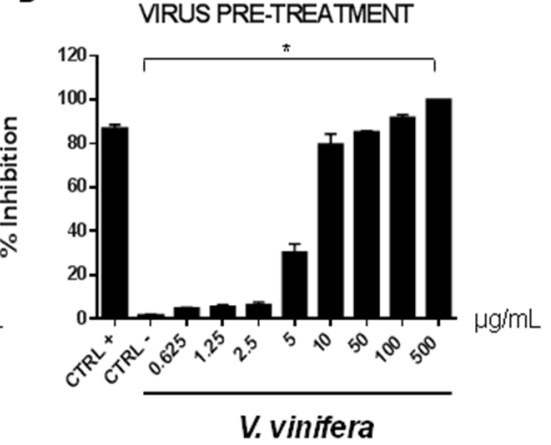

D

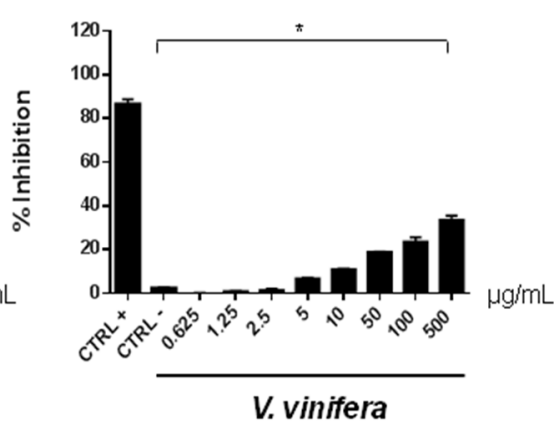

Figure 4. Antiviral effect (expressed as \% of inhibition) of leaf extract $(\mu \mathrm{g} / \mathrm{mL})$ against SARS-CoV-2 in different plaque reduction assays: (A) co-treatment; (B) virus pre-treatment; (C) post-treatment; (D) cell pre-treatment. The results presented were obtained from three independent experiments. Data are mean \pm SD. Statistical differences were analyzed via Student's $t$-test, a value of $p \leq 0.05$ was considered significant, with $* x \leq 0.05$.

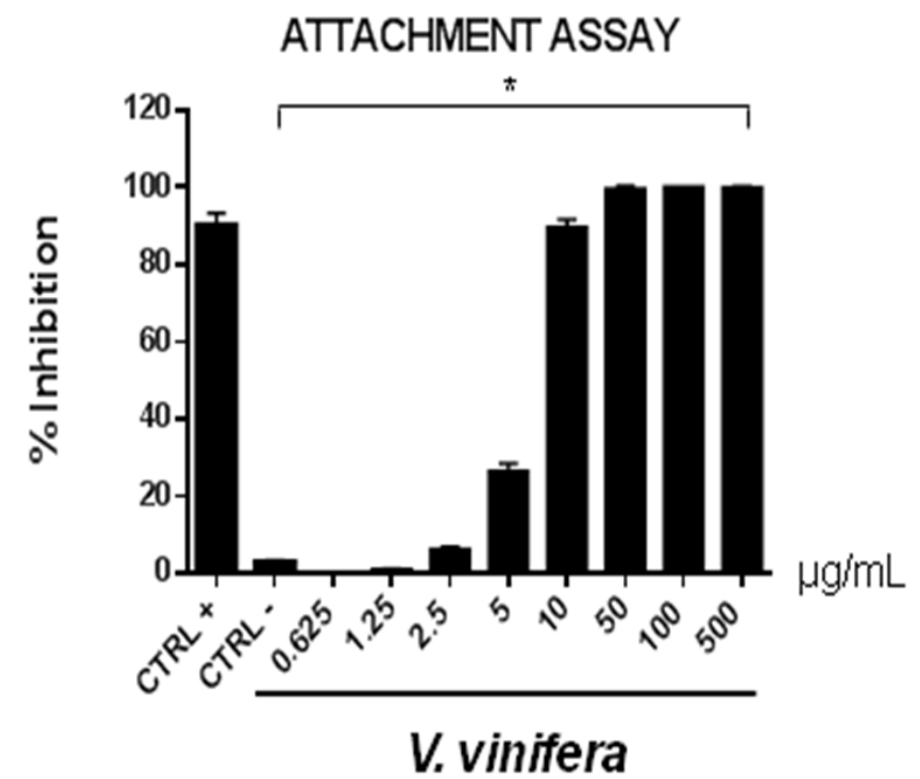

Figure 5. Early viral attachment assay of leaf extract $(\mu \mathrm{g} / \mathrm{mL})$ against HSV-1. The antiviral activity is expressed as \% of inhibition. The results presented were obtained from three independent experiments. Data are mean \pm SD. Statistical differences were analyzed via Student's $t$-test, a value of $p \leq 0.05$ was considered significant, with ${ }^{*} p \leq 0.05$. 


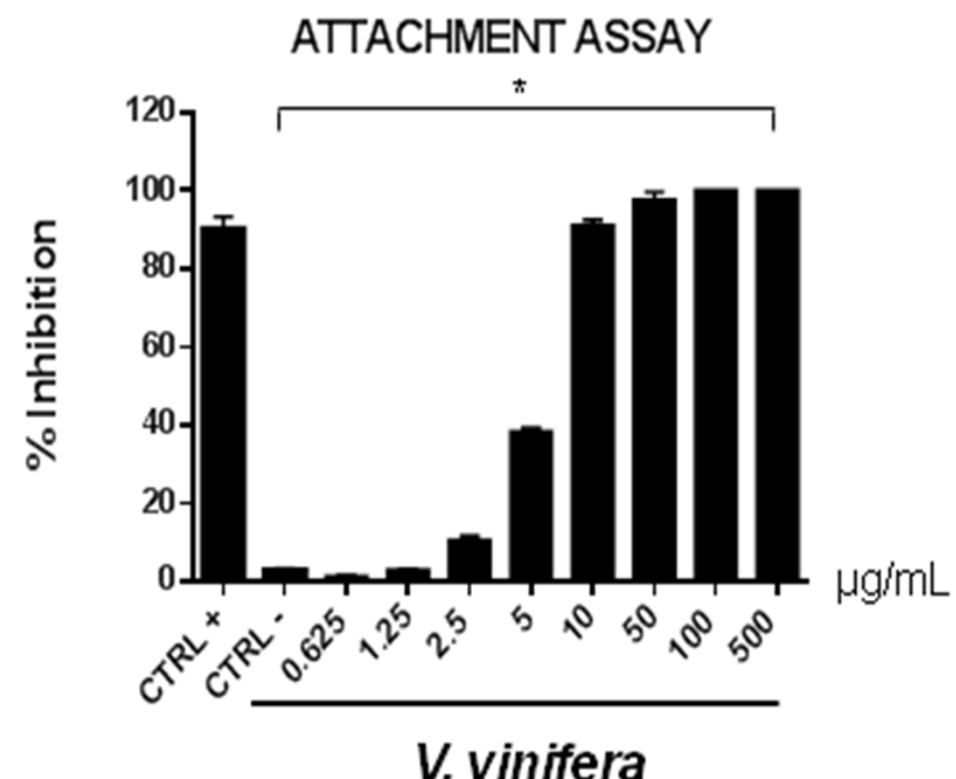

Figure 6. Early viral attachment assay of leaf extract $(\mu \mathrm{g} / \mathrm{mL})$ against SARS-CoV-2. The antiviral activity is expressed as \% of inhibition. The results presented were obtained from three independent experiments. Data are mean \pm SD. Statistical differences were analyzed via Student's $t$-test, a value of $p \leq 0.05$ was considered significant, with * $p \leq 0.05$.

The extract's inhibitory effects on virus-cell binding event revealed that it was able to block the attachment of both of the viruses into the host cell. It is most likely that leaf extract prevents the binding of viral envelope with the cell membrane and all the subsequent stages of infection by hindering some interacting site inside the viral glycoprotein deputed to the fusion, i.e., HSV-1 glycoprotein B and SARS-CoV-2 spike protein.

To validate data obtained by plaque assays, we analyzed the $V$. vinifera effect on expression genes involved in the viral infection (Figures 7 and 8).

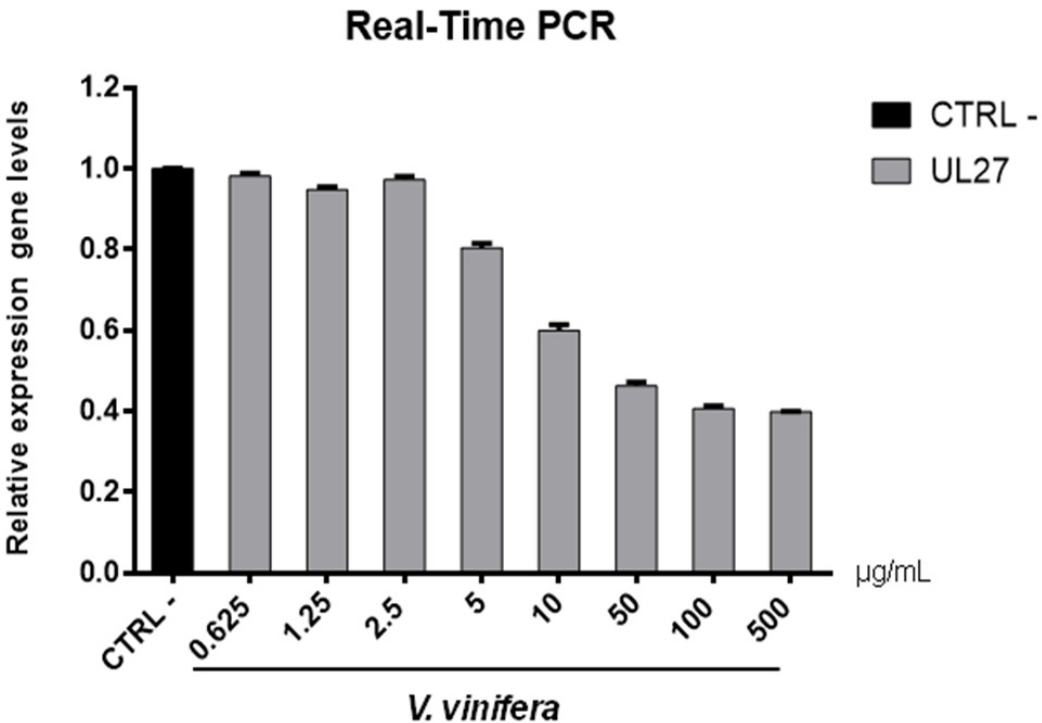

Figure 7. UL27 (glycoprotein B) gene expression analysis in Vero cells. V.vinifera leaf extract at 0.625, $1.25,2.5,5,10,50,100$, and $500 \mu \mathrm{g} / \mathrm{mL}$ was incubated with HSV-1 for $1 \mathrm{~h}$ and then, the mixture was added on Vero cells for another $1 \mathrm{~h}$. After 2 days post-infection, RNA was extracted and Real-Time PCR was performed. Relative expression gene level was calculated with respect to CTRL-. 


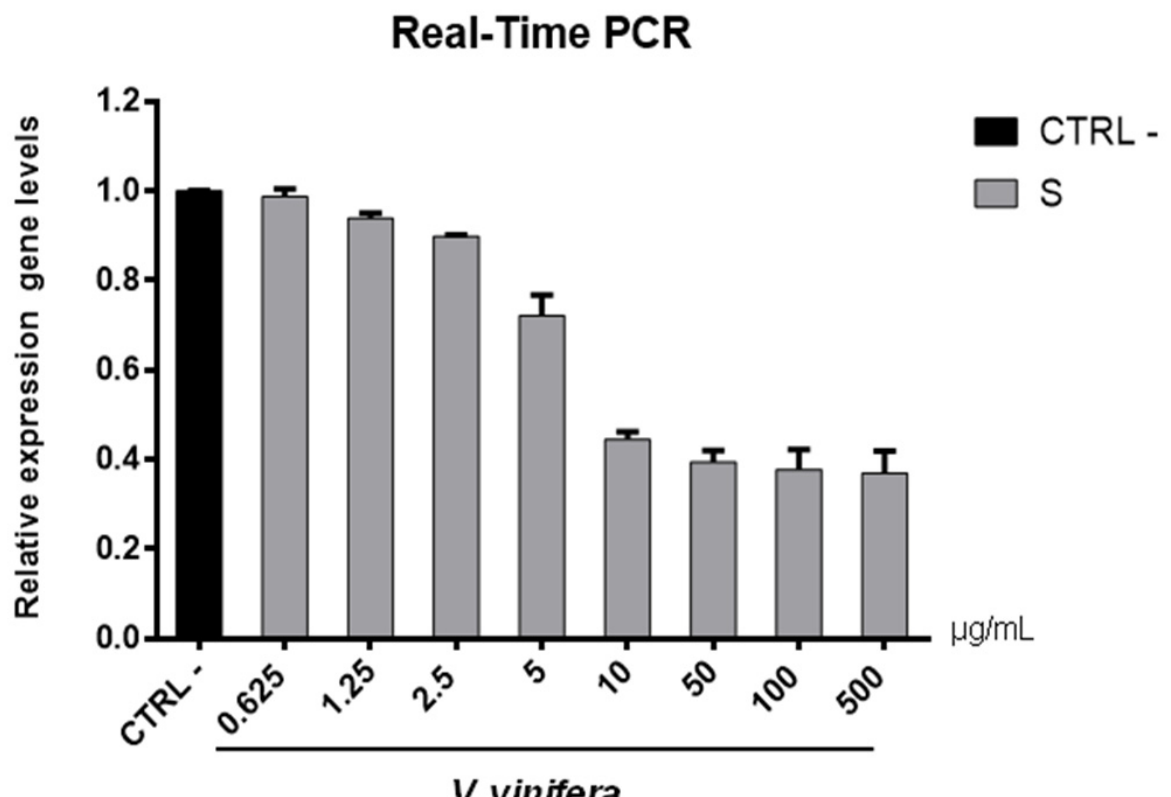

Figure 8. S gene expression analysis in Vero cells. V.vinifera leaf extract at $0.625,1.25,2.5,5,10,50$, 100 , and $500 \mu \mathrm{g} / \mathrm{mL}$ was incubated with SARS-CoV-2 for $1 \mathrm{~h}$ and then the mixture was added on Vero cells for another $1 \mathrm{~h}$. After 2 days post-infection, RNA was extracted, and Real-Time PCR was performed. Relative expression gene levels were calculated with respect to CTRL-.

Regarding the HSV-1 antiviral effect, UL27 gene, a late gene coding for the structural glycoprotein $\mathrm{B}(\mathrm{gB})$ was quantified via molecular assay (Figure 7$)$. In brief, a virus pretreatment assay was performed, as previously mentioned, and RNA was collected after $48 \mathrm{~h}$ post-infection. Results showed that the extract inhibited HSV-1 replication by blocking much of viral gene expression, which almost halved at a concentration of $10 \mu \mathrm{g} / \mathrm{mL}$. The outcomes on the replication are in accordance with literature [67-71], demonstrating that the leaf extract had a virucidal action and could be used as a prophylactic treatment for herpetic infections. Anti-SARS-CoV-2 activity of $V$. vinifera leaf extract was also investigated through the spike protein (S) gene expression (Figure 8). S protein represents the antireceptor inserted into the viral envelope essential to the attachment to the host cell via the human angiotensin-converting enzyme 2 (hACE2) receptor [72-74].

$V$. vinifera extract strongly reduced the $\mathrm{S}$ expression after SARS-CoV-2 infection until a concentration of $10 \mu \mathrm{g} / \mathrm{mL}$ was reached, and it resumed being expressed in a dosedependent manner at lower concentrations. All together, these data indicated that $V$. vinifera leaf extract possesses a great antiviral and never previously investigated activity, which was reported against SARS-CoV-2. To date, the activity of flavonoids against SARS-CoV-2 has been analyzed with promising results in silico through bioinformatics approaches [46,48,75]; in addition, the activity of these molecules towards other coronaviruses, such as the Severe acute respiratory syndrome coronavirus (SARS-CoV) and Middle East Respiratory Syndrome Coronavirus (MERS), has been widely reported [76]. Altogether these results are noteworthy, although some phenolic compounds identified in the leaf extract are already reported as antiviral agents, such as quercetin which is currently under clinical trial [77]. This study focuses on the high anti-inflammatory ability of quercetin, effective in COVID-19 treatment, and its dosage depends on the type of treatment: $500 \mathrm{mg}$ for prophylactic use and $1000 \mathrm{mg}$ for curative treatment.

\subsection{Cytotoxicity Evaluation}

In order to complete the toxicological activity of leaf extract, $V$. vinifera was tested in colon, lung, breast, cardiomyocytes, hepatocyte cancer cells, and immortalized human keratinocyte cell line for $48 \mathrm{~h}$ at four different concentrations from $65 \mu \mathrm{g} / \mathrm{mL}$ to $500 \mu \mathrm{g} / \mathrm{mL}$ 
(Figure 9A-F). With respect to the known published anticancer effect of the grape, seeds, or peel of $V$. vinifera [78], the leaf extract did not induce any substantial variation in cell cancer viability. This different response, compared to that previously reported [79], could be explained by the different extraction methodologies or $V$. vinifera varieties used. These data suggest how this complex polyphenolic extract, in these conditions, was able to selectively act on a specific target, without altering other cellular mechanisms.

A

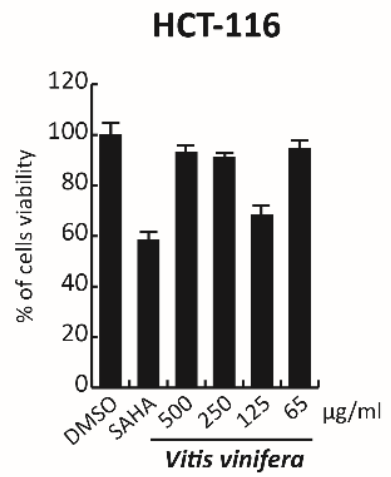

D

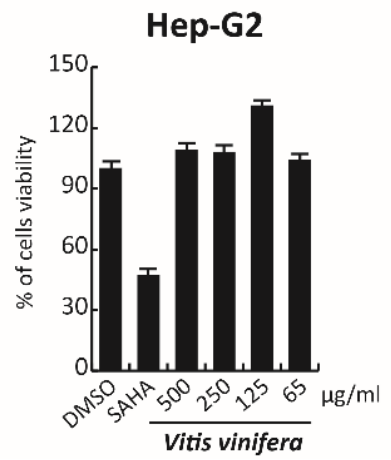

B

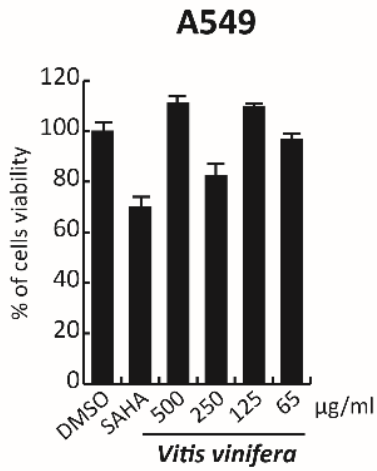

E

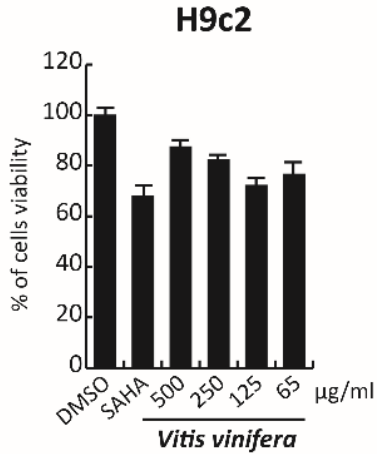

C

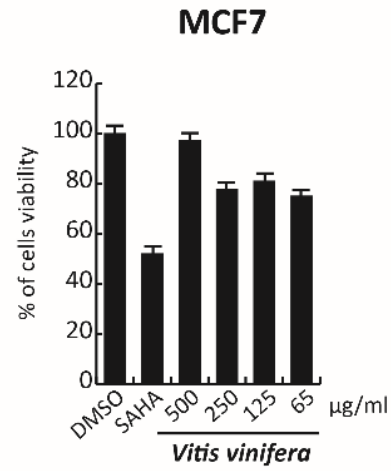

$\mathbf{F}$

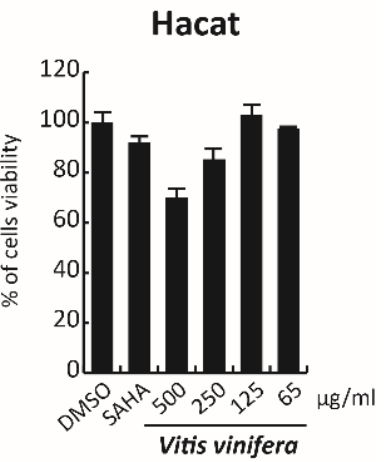

Figure 9. (A-F) Cell viability evaluation by MTT assay of HCT-116, A549, MCF7, cardiomyocytes, Hep-G2, and Hacat cells after treatment with $V$. vinifera for $48 \mathrm{~h}$ at 500, 250,125, and $65 \mu \mathrm{g} / \mathrm{mL}$. SAHA was used as a control at $5 \mu \mathrm{M}$ for $24 \mathrm{~h}$.

\section{Conclusions}

Plants represent an important source of natural products with high medical relevance [51]. Polyphenols, as flavonoids, are widespread compounds in the plant kingdom, and they are characterized by different biological activities, including antioxidant, antimicrobial, anticancer, anti-inflammatory, and antiviral properties. In this study, aqueous methanol solvent was employed to prepare raw extracts of $V$. vinifera leaves and its chemical profile was analyzed through HPLC-MS in negative ionization mode. This analysis led to the identification and characterization of 35 flavonoids, most of which were derivatives of quercetin. Others included derivatives of luteolin, kaempferol, apigenin, isorhamnetin, myricetin, chrysoeriol, biochanin, isookanin, and scutellarein. Furthermore, we tested the antiviral potential of the extract against HSV-1 and SARS-CoV-2 with very interesting results, showing the capability of flavonoids to inhibit SARS-CoV-2 for the first time. Considering the current pandemic emergency, our results represent a promising resource for pharmaceutical industrial applications.

Author Contributions: Conceptualization, G.F. and D.d.P.; methodology, C.Z., R.G., and A.C.; software, C.B. and G.A.V.; formal analysis, C.B.; investigation, C.Z., R.G., and A.C.; resources, M.G., P.T., and D.d.P.; data curation, G.S. and F.S.; writing-original draft preparation, C.Z. and R.G.; writing-review and editing, G.F., D.d.P., G.S., and A.M.; visualization, C.B. and A.N.; supervision, 
G.F., M.G., and D.d.P.; funding acquisition, M.G., L.A., and D.d.P. All authors have read and agreed to the published version of the manuscript.

Funding: CM1406/EPICHEMBIO; B63D18000560007/Campania Regional Government FASE2: IDEAL; B21C17000030007/Campania Regional Government Technology Platform Lotta alle Patologie Oncologiche: iCURE.

Acknowledgments: The authors are grateful to PRIN 2017 "Natural and pharmacological inhibition of the early phase of viral replication (VirSudNet)" N²017M8R7N9.

Conflicts of Interest: The authors declare no conflict of interest.

\section{References}

1. Rinaldi, A.; Villano, C.; Lanzillo, C.; Tamburrino, A., Jr.; Jourdes, M.; Teissedre, P.L.; Moio, L.; Frusciante, L.; Carputo, D.; Aversano, R. Metabolic and RNA profiling elucidates proanthocyanidins accumulation in Aglianico grape. Food Chem. 2017, 233, 52-59. [CrossRef] [PubMed]

2. Gratl, V.; Sturm, S.; Zini, E.; Letschka, T.; Stefanini, M.; Vezzulli, S.; Stuppner, H. Comprehensive polyphenolic profiling in promising resistant grapevine hybrids including 17 novel breeds in northern Italy. J. Sci. Food Agric. 2021, 101, 2380-2388. [CrossRef]

3. Sikuten, I.; Stambuk, P.; Andabaka, Z.; Tomaz, I.; Markovic, Z.; Stupic, D.; Maletic, E.; Kontic, J.K.; Preiner, D. Grapevine as a Rich Source of Polyphenolic Compounds. Molecules 2020, 25, 5604. [CrossRef]

4. Ju, Y.L.; Yue, X.F.; Min, Z.; Wang, X.H.; Fang, Y.L.; Zhang, J.X. VvNAC17, a novel stress-responsive grapevine (Vitis vinifera L.) NAC transcription factor, increases sensitivity to abscisic acid and enhances salinity, freezing, and drought tolerance in transgenic Arabidopsis. Plant. Physiol. Biochem. 2020, 146, 98-111. [CrossRef]

5. Batiha, G.E.; Beshbishy, A.M.; Ikram, M.; Mulla, Z.S.; El-Hack, M.E.A.; Taha, A.E.; Algammal, A.M.; Elewa, Y.H.A. The Pharmacological Activity, Biochemical Properties, and Pharmacokinetics of the Major Natural Polyphenolic Flavonoid: Quercetin. Foods 2020, 9, 374. [CrossRef]

6. Duan, J.; Zhan, J.C.; Wang, G.Z.; Zhao, X.C.; Huang, W.D.; Zhou, G.B. The red wine component ellagic acid induces autophagy and exhibits anti-lung cancer activity in vitro and in vivo. J. Cell Mol. Med. 2019, 23, 143-154. [CrossRef]

7. Saadaoui, N.; Weslati, A.; Barkaoui, T.; Khemiri, I.; Gadacha, W.; Souli, A.; Mokni, M.; Harbi, M.; Ben-Attia, M. Gastroprotective effect of leaf extract of two varieties grapevine (Vitis vinifera L.) native wild and cultivar grown in North of Tunisia against the oxidative stress induced by ethanol in rats. Biomarkers 2020, 25, 48-61. [CrossRef]

8. Fujita, K.; Aoki, Y.; Suzuki, S. Antidiabetic effects of novel cell culture established from grapevine, Vitis vinifera cv. Koshu. Cytotechnology 2018, 70, 993-999. [CrossRef] [PubMed]

9. Kim, H.Y.; Hong, M.H.; Yoon, J.J.; Kim, D.S.; Na, S.W.; Jang, Y.J.; Lee, Y.J.; Kang, D.G.; Lee, H.S. Protective Effect of Vitis labrusca Leaves Extract on Cardiovascular Dysfunction through HMGB1-TLR4-NFkappaB Signaling in Spontaneously Hypertensive Rats. Nutrients 2020, 12, 10.

10. Li, L.; Zhang, M.; Zhang, S.; Cui, Y.; Sun, B. Preparation and Antioxidant Activity of Ethyl-Linked Anthocyanin-Flavanol Pigments from Model Wine Solutions. Molecules 2018, 23, 1066. [CrossRef]

11. Squillaci, G.; Zannella, C.; Carbone, V.; Minasi, P.; Folliero, V.; Stelitano, D.; Cara, F.L.; Galdiero, M.; Franci, G.; Morana, A. Grape Canes from Typical Cultivars of Campania (Southern Italy) as a Source of High-Value Bioactive Compounds: Phenolic Profile, Antioxidant and Antimicrobial Activities. Molecules 2021, 26, 2746. [CrossRef]

12. Aliano-Gonzalez, M.J.; Richard, T.; Cantos-Villar, E. Grapevine Cane Extracts: Raw Plant Material, Extraction Methods, Quantification, and Applications. Biomolecules 2020, 10, 1195. [CrossRef] [PubMed]

13. Sanchez, M.C.; Ribeiro-Vidal, H.; Esteban-Fernandez, A.; Bartolome, B.; Figuero, E.; Moreno-Arribas, M.V.; Sanz, M.; Herrera, D. Antimicrobial activity of red wine and oenological extracts against periodontal pathogens in a validated oral biofilm model. BMC Complement. Altern Med. 2019, 19, 145. [CrossRef]

14. Lee, J.W.; Kim, Y.I.; Im, C.N.; Kim, S.W.; Kim, S.J.; Min, S.; Joo, Y.H.; Yim, S.V.; Chung, N. Grape Seed Proanthocyanidin Inhibits Mucin Synthesis and Viral Replication by Suppression of AP-1 and NF-kappaB via p38 MAPKs/JNK Signaling Pathways in Respiratory Syncytial Virus-Infected A549 Cells. J. Agric. Food Chem. 2017, 65, 4472-4483. [CrossRef] [PubMed]

15. Zhang, X.Y.; Li, W.G.; Wu, Y.J.; Zheng, T.Z.; Li, W.; Qu, S.Y.; Liu, N.F. Proanthocyanidin from grape seeds potentiates anti-tumor activity of doxorubicin via immunomodulatory mechanism. Int. Immunopharmacol. 2005, 5, 1247-1257. [CrossRef]

16. Lin, Y.S.; Chen, S.F.; Liu, C.L.; Nieh, S. The chemoadjuvant potential of grape seed procyanidins on p53-related cell death in oral cancer cells. J. Oral Pathol. Med. 2012, 41, 322-331. [CrossRef] [PubMed]

17. Zykova, T.A.; Zhu, F.; Zhai, X.; Ma, W.Y.; Ermakova, S.P.; Lee, K.W.; Bode, A.M.; Dong, Z. Resveratrol directly targets COX-2 to inhibit carcinogenesis. Mol. Carcinog. 2008, 47, 797-805. [CrossRef] [PubMed]

18. Sun, Q.; Prasad, R.; Rosenthal, E.; Katiyar, S.K. Grape seed proanthocyanidins inhibit the invasive potential of head and neck cutaneous squamous cell carcinoma cells by targeting EGFR expression and epithelial-to-mesenchymal transition. BMC Complement. Altern. Med. 2011, 11, 134. [CrossRef] [PubMed] 
19. Schlachterman, A.; Valle, F.; Wall, K.M.; Azios, N.G.; Castillo, L.; Morell, L.; Washington, A.V.; Cubano, L.A.; Dharmawardhane, S.F. Combined resveratrol, quercetin, and catechin treatment reduces breast tumor growth in a nude mouse model. Transl. Oncol. 2008, 1, 19-27. [CrossRef] [PubMed]

20. Cai, W.; Chen, G.; Luo, Q.; Liu, J.; Guo, X.; Zhang, T.; Ma, F.; Yuan, L.; Li, B.; Cai, J. PMP22 Regulates Self-Renewal and Chemoresistance of Gastric Cancer Cells. Mol. Cancer Ther. 2017, 16, 1187-1198. [CrossRef]

21. Borai, I.H.; Ezz, M.K.; Rizk, M.Z.; Aly, H.F.; El-Sherbiny, M.; Matloub, A.A.; Fouad, G.I. Therapeutic impact of grape leaves polyphenols on certain biochemical and neurological markers in AlCl3-induced Alzheimer's disease. Biomed. Pharmacother. 2017, 93, 837-851. [CrossRef]

22. Di Meo, F.; Aversano, R.; Diretto, G.; Demurtas, O.C.; Villano, C.; Cozzolino, S.; Filosa, S.; Carputo, D.; Crispi, S. Anti-cancer activity of grape seed semi-polar extracts in human mesothelioma cell lines. J. Funct. Foods 2019, 61, 103515. [CrossRef]

23. Radulescu, C.; Buruleanu, L.C.; Nicolescu, C.M.; Olteanu, R.L.; Bumbac, M.; Holban, G.C.; Simal-Gandara, J. Phytochemical Profiles, Antioxidant and Antibacterial Activities of Grape (Vitis vinifera L.) Seeds and Skin from Organic and Conventional Vineyards. Plants 2020, 9, 1470. [CrossRef] [PubMed]

24. Al-Mousawi, A.H.; Al-Kaabi, S.J.; Albaghdadi, A.J.H.; Almulla, A.F.; Raheem, A.; Algon, A.A.A. Effect of Black Grape Seed Extract (Vitis vinifera) on Biofilm Formation of Methicillin-Resistant Staphylococcus aureus and Staphylococcus haemolyticus. Curr Microbiol 2020, 77, 238-245. [CrossRef] [PubMed]

25. Pavic, V.; Kujundzic, T.; Kopic, M.; Jukic, V.; Braun, U.; Schwander, F.; Drenjancevic, M. Effects of Defoliation on Phenolic Concentrations, Antioxidant and Antibacterial Activity of Grape Skin Extracts of the Varieties Blaufrankisch and Merlot (Vitis vinifera L.). Molecules 2019, 24, 2444. [CrossRef]

26. Olejar, K.J.; Ricci, A.; Swift, S.; Zujovic, Z.; Gordon, K.C.; Fedrizzi, B.; Versari, A.; Kilmartin, P.A. Characterization of an Antioxidant and Antimicrobial Extract from Cool Climate, White Grape Marc. Antioxidants 2019, 8, 232. [CrossRef]

27. Santella, B.; Folliero, V.; Pirofalo, G.M.; Serretiello, E.; Zannella, C.; Moccia, G.; Santoro, E.; Sanna, G.; Motta, O.; De Caro, F.; et al. Sepsis-A Retrospective Cohort Study of Bloodstream Infections. Antibiotics 2020, 9, 851. [CrossRef]

28. Zannella, C.; Shinde, S.; Vitiello, M.; Falanga, A.; Galdiero, E.; Fahmi, A.; Santella, B.; Nucci, L.; Gasparro, R.; Galdiero, M.; et al. Antibacterial Activity of Indolicidin-Coated Silver Nanoparticles in Oral Disease. Appl. Sci. 2020, 10, 1837. [CrossRef]

29. Andelkovic, M.; Radovanovic, B.; Andelkovic, A.M.; Radovanovic, V. Phenolic Compounds and Bioactivity of Healthy and Infected Grapevine Leaf Extracts from Red Varieties Merlot and Vranac (Vitis vinifera L.). Plant Foods Hum. Nutr. 2015, 70, 317-323. [CrossRef] [PubMed]

30. Rodríguez Vaquero, M.J.; Alberto, M.R.; Manca de Nadra, M.C. Influence of phenolic compounds from wines on the growth of Listeria monocytogenes. Food Control. 2007, 18, 587-593. [CrossRef]

31. Papadopoulou, C.; Soulti, K.; Roussis, I. Potential Antimicrobial Activity of Red and White Wine Phenolic Extracts against Strains of Staphylococcus aureus, Escherichia coli and Candida albicans. Food Technol. Biotechnol. 2005, 43, 41-46.

32. Lin, S.C.; Ho, C.T.; Chuo, W.H.; Li, S.; Wang, T.T.; Lin, C.C. Effective inhibition of MERS-CoV infection by resveratrol. BMC Infect. Dis. 2017, 17, 144. [CrossRef]

33. Yang, T.; Li, S.; Zhang, X.; Pang, X.; Lin, Q.; Cao, J. Resveratrol, sirtuins, and viruses. Rev. Med. Virol. 2015, 25, 431-445. [CrossRef]

34. Friedman, M. Antibacterial, antiviral, and antifungal properties of wines and winery byproducts in relation to their flavonoid content. J. Agric. Food Chem. 2014, 62, 6025-6042. [CrossRef]

35. Vazquez-Calvo, A.; Jimenez de Oya, N.; Martin-Acebes, M.A.; Garcia-Moruno, E.; Saiz, J.C. Antiviral Properties of the Natural Polyphenols Delphinidin and Epigallocatechin Gallate against the Flaviviruses West Nile Virus, Zika Virus, and Dengue Virus. Front. Microbiol. 2017, 8, 1314. [CrossRef]

36. Madeddu, S.; Marongiu, A.; Sanna, G.; Zannella, C.; Falconieri, D.; Porcedda, S.; Manzin, A.; Piras, A. Bovine Viral Diarrhea Virus (BVDV): A Preliminary Study on Antiviral Properties of Some Aromatic and Medicinal Plants. Pathogens 2021, 10, 403. [CrossRef] [PubMed]

37. Matias, A.A.; Serra, A.T.; Silva, A.C.; Perdigao, R.; Ferreira, T.B.; Marcelino, I.; Silva, S.; Coelho, A.V.; Alves, P.M.; Duarte, C.M. Portuguese winemaking residues as a potential source of natural anti-adenoviral agents. Int. J. Food Sci. Nutr. 2010, 61, 357-368. [CrossRef]

38. Sharaf, M.; El-Deeb, N.; Eladawi, H. The Potentiality of Grape Seed Extract as a Novel Anti-hepatitis C virus Agent. J. Med. Sci. 2012, 12, 107. [CrossRef]

39. Su, X.; D'Souza, D.H. Grape seed extract for control of human enteric viruses. Appl. Environ. Microbiol. 2011, 77, 3982-3987. [CrossRef] [PubMed]

40. World Health Organization. Massive Proportion of World's Population Are Living with Herpes Infection; World Health Organization: Geneva, Switzerland, 2020.

41. World Health Organization. Globally, an Estimated Two-Thirds of the Population Under 50 are Infected with Herpes Simplex Virus Type 1; World Health Organization: Geneva, Switzerland, 2015.

42. Stelitano, D.; Franci, G.; Chianese, A.; Galdiero, S.; Morelli, G.; Galdiero, M. HSV membrane glycoproteins, their function in viral entry and their use in vaccine studies. In Amino Acids, Peptides and Proteins: Volume 43; The Royal Society of Chemistry: London, UK, 2019; Volume 43, pp. 14-43.

43. World Health Organization. WHO Coronavirus (COVID-19) Dashboard; World Health Organization: Geneva, Switzerland, 2021. 
44. Martines, R.B.; Ritter, J.M.; Matkovic, E.; Gary, J.; Bollweg, B.C.; Bullock, H.; Goldsmith, C.S.; Silva-Flannery, L.; Seixas, J.N.; Reagan-Steiner, S.; et al. Pathology and Pathogenesis of SARS-CoV-2 Associated with Fatal Coronavirus Disease, United States. Emerg. Infect. Dis. 2020, 26, 2005-2015. [CrossRef]

45. Docimo, T.; Francese, G.; Ruggiero, A.; Batelli, G.; De Palma, M.; Bassolino, L.; Toppino, L.; Rotino, G.L.; Mennella, G.; Tucci, M. Phenylpropanoids Accumulation in Eggplant Fruit: Characterization of Biosynthetic Genes and Regulation by a MYB Transcription Factor. Front. Plant. Sci. 2015, 6, 1233. [CrossRef]

46. Pandey, P.; Khan, F.; Rana, A.K.; Srivastava, Y. A drug repurposing approach towards elucidating the potential of flavonoids as COVID-19 spike protein inhibitors. Biointerface Res. Appl. Chem. 2021, 11, 8482-8501.

47. Sukovic, D.; Knezevic, B.; Gasic, U.; Sredojevic, M.; Ciric, I.; Todic, S.; Mutic, J.; Tesic, Z. Phenolic Profiles of Leaves, Grapes and Wine of Grapevine Variety Vranac (Vitis vinifera L.) from Montenegro. Foods 2020, 9, 138. [CrossRef]

48. Mouffouk, C.; Mouffouk, S.; Mouffouk, S.; Hambaba, L.; Haba, H. Flavonols as potential antiviral drugs targeting SARS-CoV-2 proteases (3CL(pro) and PL(pro)), spike protein, RNA-dependent RNA polymerase (RdRp) and angiotensin-converting enzyme II receptor (ACE2). Eur. J. Pharmacol. 2021, 891, 173759. [CrossRef] [PubMed]

49. Yao, X.; Ye, F.; Zhang, M.; Cui, C.; Huang, B.; Niu, P.; Liu, X.; Zhao, L.; Dong, E.; Song, C.; et al. In Vitro Antiviral Activity and Projection of Optimized Dosing Design of Hydroxychloroquine for the Treatment of Severe Acute Respiratory Syndrome Coronavirus 2 (SARS-CoV-2). Clin. Infect. Dis. 2020, 71, 732-739. [CrossRef] [PubMed]

50. Singh, M.; Zannella, C.; Folliero, V.; Di Girolamo, R.; Bajardi, F.; Chianese, A.; Altucci, L.; Damasco, A.; Del Sorbo, M.R.; Imperatore, C.; et al. Combating Actions of Green 2D-Materials on Gram Positive and Negative Bacteria and Enveloped Viruses. Front. Bioeng. Biotechnol. 2020, 8, 569967. [CrossRef] [PubMed]

51. Ferhi, S.; Santaniello, S.; Zerizer, S.; Cruciani, S.; Fadda, A.; Sanna, D.; Dore, A.; Maioli, M.; D’Hallewin, G. Total Phenols from Grape Leaves Counteract Cell Proliferation and Modulate Apoptosis-Related Gene Expression in MCF-7 and HepG2 Human Cancer Cell Lines. Molecules 2019, 24, 612. [CrossRef]

52. Hassan, W.H.B.; Abdelaziz, S.; Al Yousef, H.M. Chemical Composition and Biological Activities of the Aqueous Fraction of Parkinsonea aculeata L. Growing in Saudi Arabia. Arab. J. Chem. 2019, 12, 377-387. [CrossRef]

53. Pluskal, T.; Castillo, S.; Villar-Briones, A.; Oresic, M. MZmine 2: Modular framework for processing, visualizing, and analyzing mass spectrometry-based molecular profile data. BMC Bioinform. 2010, 11, 395. [CrossRef]

54. Wang, M.; Carver, J.J.; Phelan, V.V.; Sanchez, L.M.; Garg, N.; Peng, Y.; Nguyen, D.D.; Watrous, J.; Kapono, C.A.; Luzzatto-Knaan, T.; et al. Sharing and community curation of mass spectrometry data with Global Natural Products Social Molecular Networking. Nat. Biotechnol. 2016, 34, 828-837. [CrossRef]

55. Vitale, G.A.; Sciarretta, M.; Cassiano, C.; Buonocore, C.; Festa, C.; Mazzella, V.; Nunez Pons, L.; D'Auria, M.V.; de Pascale, D. Molecular Network and Culture Media Variation Reveal a Complex Metabolic Profile in Pantoea cf. eucrina D2 Associated with an Acidified Marine Sponge. Int. J. Mol. Sci. 2020, 21, 6307. [CrossRef]

56. Brito, A.; Ramirez, J.E.; Areche, C.; Sepulveda, B.; Simirgiotis, M.J. HPLC-UV-MS profiles of phenolic compounds and antioxidant activity of fruits from three citrus species consumed in Northern Chile. Molecules 2014, 19, 17400-17421. [CrossRef]

57. Geng, P.; Sun, J.; Zhang, M.; Li, X.; Harnly, J.M.; Chen, P. Comprehensive characterization of C-glycosyl flavones in wheat (Triticum aestivum L.) germ using UPLC-PDA-ESI/HRMS(n) and mass defect filtering. J. Mass Spectrom. 2016, 51, 914-930. [CrossRef]

58. Elsadig Karar, M.; Kuhnert, N. UPLC-ESI-Q-TOF-MS/MS Characterization of Phenolics from Crataegus monogyna and Crataegus laevigata (Hawthorn) Leaves, Fruits and their Herbal Derived Drops (Crataegutt Tropfen). J. Chem. Biol. Ther. 2016, 1, 102. [CrossRef]

59. Spinola, V.; Llorent-Martinez, E.J.; Castilho, P.C. Antioxidant polyphenols of Madeira sorrel (Rumex maderensis): How do they survive to in vitro simulated gastrointestinal digestion? Food Chem. 2018, 259, 105-112. [CrossRef] [PubMed]

60. Dueñas, M.; Mingo-Chornet, H.; Pérez-Alonso, J.; Di Paola, R.; Gonzalez-paramas, A.M.; Santos Buelga, C. Preparation of quercetin glucuronides and characterization by HPLC-DAD-ESI/MS. Eur. Food Res. Technol. 2008, 227, 1069-1076. [CrossRef]

61. Chen, G.; Li, X.; Saleri, F.; Guo, M. Analysis of Flavonoids in Rhamnus davurica and Its Antiproliferative Activities. Molecules 2016, 21, 1275. [CrossRef]

62. Roriz, C.L.; Barros, L.; Carvalho, A.M.; Santos-Buelga, C.; Ferreira, I.C. Scientific validation of synergistic antioxidant effects in commercialised mixtures of Cymbopogon citratus and Pterospartum tridentatum or Gomphrena globosa for infusions preparation. Food Chem. 2015, 185, 16-24. [CrossRef]

63. Marczak, Ł.; Znajdek-Awiżeń, P.; Bylka, W. The Use of Mass Spectrometric Techniques to Differentiate Isobaric and Isomeric Flavonoid Conjugates from Axyris amaranthoides. Molecules 2016, 21, 1229. [CrossRef]

64. World Health Organization. Coronavirus Disease (COVID-19) Pandemic; World Health Organization: Geneva, Switzerland, 2020.

65. Chianese, A.; Santella, B.; Ambrosino, A.; Stelitano, D.; Rinaldi, L.; Galdiero, M.; Zannella, C.; Franci, G. Oncolytic Viruses in Combination Therapeutic Approaches with Epigenetic Modulators: Past, Present, and Future Perspectives. Cancers 2021, 13, 2761. [CrossRef]

66. Falanga, A.; Del Genio, V.; Kaufman, E.A.; Zannella, C.; Franci, G.; Weck, M.; Galdiero, S. Engineering of Janus-Like Dendrimers with Peptides Derived from Glycoproteins of Herpes Simplex Virus Type 1: Toward a Versatile and Novel Antiviral Platform. Int. J. Mol. Sci. 2021, 22, 6488. [CrossRef]

67. Monda, V.; Valenzano, A.; Monda, M. Modifications of Activity of Autonomic Nervous System, and Resting Energy Expenditure in Women Using Hormone-Replacement Therapy. Biol. Med. 2016, 8, 1. 
68. Schiattarella, A.; Riemma, G.; La Verde, M.; Franci, G.; Chianese, A.; Fasulo, D.; Fichera, M.; Gallo, P.; De Franciscis, P. Polycystic ovary syndrome and probiotics: A natural approach to an inflammatory disease. Curr. Womens Health Rev. 2021, 17, 14-20. [CrossRef]

69. Russo, M.; Moccia, S.; Spagnuolo, C.; Tedesco, I.; Russo, G.L. Roles of flavonoids against coronavirus infection. Chem. Biol. Interact. 2020, 328, 109211. [CrossRef]

70. Urmenyi, F.G.; Saraiva, G.D.; Casanova, L.M.; Matos, A.D.; de Magalhaes Camargo, L.M.; Romanos, M.T.; Costa, S.S. Anti-HSV-1 and HSV-2 Flavonoids and a New Kaempferol Triglycoside from the Medicinal Plant Kalanchoe daigremontiana. Chem. Biodivers. 2016, 13, 1707-1714. [CrossRef]

71. Abdallah, H.M.; El-Halawany, A.M.; Sirwi, A.; El-Araby, A.M.; Mohamed, G.A.; Ibrahim, S.R.M.; Koshak, A.E.; Asfour, H.Z.; Awan, Z.A. Repurposing of Some Natural Product Isolates as SARS-COV-2 Main Protease Inhibitors via In Vitro Cell Free and Cell-Based Antiviral Assessments and Molecular Modeling Approaches. Pharmaceuticals 2021, 14, 213. [CrossRef]

72. Conceicao, C.; Thakur, N.; Human, S.; Kelly, J.T.; Logan, L.; Bialy, D.; Bhat, S.; Stevenson-Leggett, P.; Zagrajek, A.K.; Hollinghurst, P.; et al. The SARS-CoV-2 Spike protein has a broad tropism for mammalian ACE2 proteins. PLoS Biol. 2020, 18, e3001016. [CrossRef]

73. Hoffmann, M.; Kleine-Weber, H.; Schroeder, S.; Kruger, N.; Herrler, T.; Erichsen, S.; Schiergens, T.S.; Herrler, G.; Wu, N.H.; Nitsche, A.; et al. SARS-CoV-2 Cell Entry Depends on ACE2 and TMPRSS2 and Is Blocked by a Clinically Proven Protease Inhibitor. Cell 2020, 181, 271-280.e8. [CrossRef]

74. Zhao, P.; Praissman, J.L.; Grant, O.C.; Cai, Y.; Xiao, T.; Rosenbalm, K.E.; Aoki, K.; Kellman, B.P.; Bridger, R.; Barouch, D.H.; et al. Virus-Receptor Interactions of Glycosylated SARS-CoV-2 Spike and Human ACE2 Receptor. Cell Host Microbe 2020, 28, 586-601.e6. [CrossRef]

75. Jain, A.S.; Sushma, P.; Dharmashekar, C.; Beelagi, M.S.; Prasad, S.K.; Shivamallu, C.; Prasad, A.; Syed, A.; Marraiki, N.; Prasad, K.S. In silico evaluation of flavonoids as effective antiviral agents on the spike glycoprotein of SARS-CoV-2. Saudi J. Biol. Sci. 2021, 28, 1040-1051. [CrossRef] [PubMed]

76. Taban, A.K.; Süntar, İ. An Overview on Flavonoids as Potential Antiviral Strategies against Coronavirus Infections. Gazi Med. J. 2020. [CrossRef]

77. Effect of Quercetin on Prophylaxis and Treatment of COVID-19. Available online: https://clinicaltrials.gov/ct2/show/NCT043 77789 (accessed on 28 June 2021).

78. Grace Nirmala, J.; Evangeline Celsia, S.; Swaminathan, A.; Narendhirakannan, R.T.; Chatterjee, S. Cytotoxicity and apoptotic cell death induced by Vitis vinifera peel and seed extracts in A431 skin cancer cells. Cytotechnology 2018, 70, 537-554. [CrossRef] [PubMed]

79. Abed, A.; Harb, J.; Khasib, S.; Saad, B. In vitro assessment of cytotoxic, antioxidant and antimicrobial activities of leaves from two grape varieties collected from arid and temperate regions in Palestine. QSci. Connect 2015, 2015, 4. 